\title{
Dilution and Anti-Dilution: A Reply to Professor Kaplan
}

\author{
David L. Ratner
}

Professor Stanley Kaplan, in the Autumn issue of the Review, has pointed out that the "anti-dilution" provisions of convertible securities should not be considered as "boilerplate" to be copied from the handiest available precedent. ${ }^{1}$ Any presentation which helps to clarify the basic problems and the relevant choices in this arcane subject is welcome. However, Professor Kaplan's discussion of the respective merits of the "conversion price" formula and the "market price" formula ${ }^{2}$ seems to me to involve some dubious assumptions and may mislead lawyers into believing that the conversion price formula, despite its greater complexity and its lack of logical basis of support, is always of greater benefit to the holder of the convertible security than is the market price formula.

The principal affirmative arguments that Professor Kaplan advances for the conversion price formula are that it is "traditional" and that it produces a "windfall" for the holder of a convertible security whenever the market for the underlying security has declined below the conversion price and the corporation issues an additional amount of the underlying security at the current market price. ${ }^{3}$ The only hint of a theoretical underpinning for the conversion price formula is provided, ironically, in a quote from an adherent of the market price formula, who asserts that the conversion price formula "is designed to preserve the intrinsic value of the conversion privilege as it existed at the time of the issuance of the convertible security, determined on

David L. Ratner, Associate Professor of Law, Cornell Law School, is a member of the New York bar. He received his B.A. in 1952 and his LL.B. in 1955 from Harvard University.

1 Kaplan, Piercing the Corporate Boilerplate: Anti-Dilution Clauses in Convertible Securities, 33 U. CHI. L. REv. 1 (1965).

2 Briefly, the conversion price formula provides for adjustments in the conversion price when additional shares of the underlying security are sold at a price below the conversion price; the market price formula provides for adjustments when additional shares are sold to shareholders at a price below their current market value. For a fuller description, see Kaplan, supra note 1, at 4-10.

3 Id. at 24. 
the assumption that the underlying security had at that time a potential value at least equal to the original conversion price." 4

Be that as it may, Professor Kaplan finds a number of "problems" in the operation of the market price formula so significant that he suggests that "a convertible security which contains a traditional conversion price clause should be of greater value to the convertible security holder and should accordingly sell at a higher price than a comparable convertible security containing a market price clause."5 What are these "problems"?

First, "it may be argued that the holder of convertible securities is more likely to have a short-run concept of his investment than is the common stockholder; hence it may not be sufficient or appropriate to regard him as a common stockholder or to put him in a position where his interest can be diluted merely because of a price change in the stock market." 6

I am not at all clear what the relevance of the "short-run concept" is. Presumably the convertible security holder has the same interest as the common stockholder in seeing the common stock rise in value and will not automatically convert his security into common stock as soon as the market price of the latter rises above the conversion price. ${ }^{7}$ But more important, I cannot see how the "interest" of the convertible security holder is "diluted" in any ordinary sense of the word when a corporation issues shares of common stock at the current market price but below the conversion price. Assume that a corporation has two series of convertible securities outstanding. Series $A$ is convertible into common stock at a price of $\$ 10$ a share; Series $B$ is convertible into common stock at a price of $\$ 6$ a share. The holders of each series have an "interest" in every fluctuation in the market price of the common stock. The corporation sells 10,000 shares of common stock at $\$ 8$ a share, which is the current market price. Under the conversion price formula, the "interest" of the holders of Series $A$ has been "diluted," while the "interest" of the holders of Series $B$ has not. Yet there is no possibility that the holders of Series $A$ can suffer any disadvantage as a result of the issuance of shares at $\$ 8$ which will not fall equally on the holders of Series $B$. In fact, the opposite is true. If the

$4 I d$. at 10 n.21. I do not know what that means. But see note 19 infra.

5 Id. at 27 .

B Id. at 22-23.

7 Professor Buxbaum considers the market price formula "an admission that the theoretical bases for the existence of convertible securities are false," since it recognizes that the holders of a convertible security will retain it even though the market price of the underlying security has risen above the conversion price. Buxbaum, Preferred StockLaw and Draftsmanship, 42 CALIF. L. REv. 243, 284 (1954). 
issuance of shares at $\$ 8$ causes the market price of the common stock to remain at $\$ 8$ instead of going to $\$ 9$, the holders of Series $B$ will be hurt, but the holders of Series $A$ will be unaffected, since they have no "interest" in fluctuations in the market price of the common stock if the market price of the common stock would never have reached the conversion price in any event. I find it hard to conclude that an adjustment of the conversion price of the $\$ 10$ issue is anything but a "windfall," as Professor Kaplan subsequently recognizes. ${ }^{8}$

In a sense, every issue of additional common stock "dilutes" the interests of present and potential stockholders by increasing the number of shares over which the total voting power and the total equity interest are spread: ${ }^{9}$ Thus, if a convertible security holder can convert his security into a number of shares which will represent a majority of the outstanding shares and if acquisition of a majority of the shares is important to him, any issuance of additional shares at any price will "dilute" his interest in a meaningful way, and the "anti-dilution" provisions of his security should either prohibit the issuance of additional shares or provide for a pro rata adjustment of the conversion ratio whenever the corporation issues any shares. However, the only "interest" of the convertible security holders with whom Professor Kaplan is concerned is in the economic or market value of the underlying securities. Their "interest" is "diluted" only when the corporation takes some action which causes a portion of the value that would otherwise have accrued to the shares issuable on conversion of the convertible securities to be diverted to other securities or security holders, which in turn results in the underlying securities not reaching as high a value as they would have reached if such action had not been taken. If a corporation sells common stock to the public, or to its stockholders, at $\$ 8$ a share when the market price is $\$ 8$ a share, there is no dilution of the interests of convertible security holders, whether their conversion price is $\$ 6$, or $\$ 10$, or any other figure.10 The corporation may be ill-advised in selling stock at a time when the market is low, but it is not the function of anti-dilution provisions

8 Kaplan, supra note 1 , at 24.

O See, e.g., N.Y. Bus. CoRp. LAw § 622, giving shareholders the preemptive right to subscribe to additional shares the issuance of which would "adversely affect" their "unlimited dividend rights" or "voting rights." See also Berle, Corporate Devices for Diluting Stock Participations, 31 Colum. L. REv. 1239 (1931).

10 "Dilution" has been defined as "an increase in the number of shares without a corresponding increase in assets and earning power." GRAHAM, DODD \& CoTrLE, SECURITY ANALYSIS 615 (4th ed. 1962). But when does the number of shares "correspond" with the consideration received for their issuance? If the shares are publicly traded, is it not when the consideration is equal to the price that would be paid on a sale of already outstanding shares, i.e., the market price? 
to protect convertible security holders against the possible bad judgment of the corporation's directors in timing its security issues, any more than to protect against bad judgment in production, or sales, or any other aspect of the management of the business.

The second "problem" that Professor Kaplan finds in the market price formula is the uncertainty "that the holder of convertible securities will be in a position to institute a suit to enjoin . . . misconduct .. . of the kind which this clause leaves to be guarded by the restraints of general corporate law."11

I, however, do not see that there is any essential difference between the market price and conversion price formulas in this area. As Professor Kaplan himself notes, "none of the types of anti-dilution clauses, whether constructed on the conversion price or the market value formula, is impervious to evasion."12 Whichever formula is used, additional provisions may be added to cover unusual transactions not fitting within the basic anti-dilution provisions. Perhaps Professor Kaplan was thinking of the possibility that the corporation would issue common stock to persons other than stockholders below the current market price, which an exponent of the market price formula suggested to him as a contingency which might be "left to the protection of basic corporate law or to good faith valuations by the board of directors." 13 But the conversion price formula which Professor Kaplan espouses offers extra protection to the convertible security holder in this situation only if the underlying security is sold at a price below the conversion price as well as below the market price. For example, if the conversion price is $\$ 10$, the current market price of the underlying security $\$ 25$, and the corporation sells a substantial block of the underlying security at $\$ 12$, the holder of the convertible security with a conversion price formula not only gets no adjustment under his antidilution provisions; he also has arguably abandoned any right to question the fairness of the transaction. By pegging his right to an adjustment to the arbitrary and irrelevant factor of the conversion price, regardless of intent, he could well be said to have conceded a lack of "interest" in any sales above the conversion price.

In any event, I cannot see why Professor Kaplan is so concerned with the convertible security holder's right to enjoin the transaction. The security holder's interest is in his contractual right to acquire a certain amount of the underlying security in exchange for his present security; there should be no question of the corporation's right to turn

11 Kaplan, supra note 1, at 23.

$12 \mathrm{Id}$. at 17.

13 Id. at $21-22$ n.31. 
its capital structure upside down and inside out, if it so desires, as long as the appropriate adjustments are made in the conversion price.

Third is "the difficult problem of proving a deviation from market price in sales to common shareholders."14 But, as Professor Kaplan notes three pages later, this problem is generally taken care of by defining the term "market price" in the formula, with alternative provisions depending on whether the underlying security is traded on a stock exchange or in the over-the-counter market at the time the offering to shareholders is made. ${ }^{15} \mathrm{I}$ will readily concede that a market price formula will not work for a corporation whose securities are not publicly traded. But the common shareholders of a publicly-held corporation know perfectly well when shares are being offered to them below market price, and there is no special difficulty in showing whether there is a discount and approximately how large it is.

The fourth "problem" is that "the market price clause deprives the convertible security holder of some windfalls . . . which have been built into the traditional conversion price clauses" and that there are "questions of propriety and fairness" as to "whether such implicit understandings should be lightly abandoned without fanfare or public notice."16 My understanding of this passage is that Professor Kaplan concedes that the conversion price formula is, in certain circumstances, unduly generous to the holders of the convertible security at the expense of the holders of the underlying security, but that he would be ready to abandon it only after a flourish of trumpets signifying the end of the era of injustice. If that is the case, let the trumpets sound (and, for good measure, let us adopt Professor Kaplan's suggestion that prospectuses for public issues of convertible securities should describe the basic anti-dilution provisions ${ }^{17}$ ).

But I am not really convinced that the fanfare is necessary, since the conversion price formula may be more notable for its pitfalls than its windfalls. As an example of a device available to an unscrupulous board of directors to defeat the protection of the market price formula, Professor Kaplan hypothesizes that the directors of a corporation, having sold securities convertible into common stock at $\$ 10$, wish to sell additional shares of common stock to the shareholders while the market price is $\$ 10$. Their first step is to cut the dividend in half, which causes the market price to drop to $\$ 8$. They then offer additional stock to the shareholders at "the new market price of $\$ 8$ " and, for reasons

14 Id. at 23 .

$15 I d$. at 26.

16 Id. at 24.

17 Id. at 27 n.37. 
known only to Professor Kaplan, the shareholders buy it. The directors then restore the dividend, the market price rebounds to $\$ 10$, and "the outcome of this series of events is an actual dilution."18

Let me suggest instead the following counter-example, which reflects to a greater extent not only corporate reality but also the long-term inflation in security prices which is an important factor in the current popularity of convertible securities. A corporation has sold securities convertible into common stock at $\$ 10$ a share. The market price of the common stock is now $\$ 25$ a share. The corporation wishes to raise an additional $\$ 2,000,000$ by offering additional shares to its present shareholders. It can raise the money by offering 80,000 shares at $\$ 25$, 100,000 shares at $\$ 20$, or 200,000 shares at $\$ 10$. The first alternative is unrealistic; the shareholders are unlikely to subscribe unless the offering is made at a substantial discount from market price. The second involves some dilution, but a reasonable amount designed to assure a successful offering. The third alternative involves substantial dilution, the purpose of which can only be to worsen the position of the convertible security holders vis-à-vis the present common stockholders. The market price formula would provide for adjustment of the conversion price in either the second or third situation, with the amount of adjustment proportional to the amount of the dilution. The conversion price formula would not provide any adjustment in either situation, ${ }^{19}$ and the only way the holders of the convertible security could protect themselves from dilution would be to convert their security into common stock before the record date for the offering. ${ }^{20}$

$18 \mathrm{Id}$. at 25. While this might be thought to be an unduly imaginative hypothetical example, it compares favorably in realism with the alternative suggestion that the directors might seek to benefit the common shareholders at the expense of the convertible security holders by offering additional shares to the common shareholders "at the new low prices" prevailing "during a market decline following such an event as President Eisenhower's heart attack or President Kennedy's assassination." Id. at 26.

19 A similar example has been cited as illustrating that the effect of the conversion price formula "is to preserve only the principal or par value of the [convertible security] ... against dilution. If a convertible is selling considerably above par, the premium will still be subject to impairment through additional stock issues or a special dividend." Graham, DODd \& CoTrLE, supra note 10, at 615-16. (Emphasis in original.) This statement indicates a misconception about the purpose of convertibility which is perhaps partly responsible for the prevalence of the conversion price formula. If a convertible security has a principal or par value of $\$ 1,000$, the purpose of making it convertible into common stock, which fluctuates in value, is to make it possible for the convertible security holder to recognize more than $\$ 1,000$ on disposition of his security; his right to receive at least $\$ 1,000$ is protected by other preferential provisions in the indenture or certificate under which the convertible security was issued. In other words, the "premium" is the only thing with which the conversion provisions are concerned.

20 Of course it can be argued that if the market price is above the conversion price, the only protection the convertible security holder needs is sufficient notice to enable 
Even if the convertible security holders could show that the directors had chosen the third alternative solely to worsen their position, they would have no complaint. The same principle and enabling language which give the right to an adjustment upon any sale below the con. version price, regardless of motive or the existence of any "dilution" in the real sense, operate in the same way to deny an adjustment for any sale above the conversion price, regardless of motive or the existence of any real "dilution."

Professor Kaplan refers to the kind of situation described in the last paragraph as "one rare circumstance under which the market price clause will produce benefits for holders of the convertible securities which would not be obtainable under the standard conversion price clause."21 Given a period of steadily rising security prices, I wonder how rare it is. Like Professor Kaplan, I have no statistics to show in how many of the convertible securities issued in recent years the market price formula would have produced more favorable adjustments for the holders of the security, and in how many the conversion price formula would have produced the more favorable results. However, I am not sure that this lack of statistical evidence is a real handicap to the lawyer who must choose, or provide a sufficient explanation to enable his client to choose, on a pragmatic basis, either the market or conversion price formula in a particular case. If the best guess of the security buyer is that the underlying security may rise substantially in value and that the corporation may obtain additional financing by rights offerings to its shareholders, the market price formula is more likely to result in adjustments. On the other hand, if the past record indicates that the common stock will fluctuate below, as well as above, the conversion price and that the corporation, for some reason, is likely to sell additional shares to the public or to its stockholders when

him to convert before the record date, and that the market price formula in this situation "gives the [convertible security holder] . . . more than he bargained for, since it protects as an investment the speculative gain accrued to this time." Buxbaum, supra note 7, at 284. (Emphasis in original.) In fact, if a convertible security is redeemable, as they usually are, it could even be said that any corporate action which would result in dilution of the conversion right at a time when the market price of the underlying security was above the conversion price was simply an alternative to redemption as a means of forcing conversion. The only trouble with these arguments, which to my mind are the most cogent criticisms of the market price formula, is that they prove too much. To the extent that they are valid in respect to sales of additional shares to the shareholders at bargain prices, they are also valid as to stock dividends or any other gratuitous distributions. The only answer is that the convertible security holders should not be coerced into surrendering either their preferred position or a portion of their "accrued gain" unless the corporation is prepared to take the forthright step of calling the convertible securities for redemption.

21 Kaplan, supra note 1, at 24 n.32. 
the market is at its low point, the conversion price formula may be a better bet for the security holder. Any assumptions of this kind are of course extremely speculative, but they represent a more analytical approach than the choice of a "traditional" formula which promises "windfalls."

Bargaining considerations aside, I suggest that the market price formula should be the normal starting point in the preparation of anti-dilution provisions. It is much easier to understand and much easier to justify to an issuer or purchaser unfamiliar with the esoterica of convertible securities than any version of the competing conversion price formula. And I do not think the problems attributed to it are really that serious.

One final thought. Professor Kaplan takes comfort in the fact that the final draft of the model debenture indenture prepared by the American Bar Foundation contains no "boilerplate" anti-dilution clause, since "it is apparent that anti-dilution clauses should be classified as negotiable." 22 But to say that there may be important and negotiable differences between the market and conversion price formulas is not to conclude that models of the different basic formulas would not be helpful. Drafting anti-dilution provisions from scratch is a time-consuming proposition, and the risk of serious gaps in protection from inadequate drafting or the choice of an inappropriate precedent is substantially greater than any dangers involved in choosing among the recognized formulas. ${ }^{23}$

22 Id. at 30 n.39.

23 A "Commentaries Committee" of the group which prepared the model debenture indenture "has now enlisted the aid of thirteen nationally-known experts to prepare practical articles explaining and analyzing each negotiable provision and presenting samples of how they are handled in actual transactions." Rodgers, The Corporate Trust Indenture Project, 20 Bus. LAw. 551, 569 (1965). 